The Canadian Mineralogist

Vol. 42, pp. 689-694 (2004)

\title{
HYDROGEN IN A NATURAL Pd-O COMPOUND FROM GONGO SOCO, MINAS GERAIS, BRAZIL
}

\author{
AlexandRe Raphael CABRAL ${ }^{\S}$ AND BeRnd LEHMANN \\ Institut für Mineralogie und Mineralische Rohstoffe, Technische Universität Clausthal, \\ Adolph-Roemer-Str. 2A, D-38678 Clausthal-Zellerfeld, Germany \\ DiETER GRAMBOLE ${ }^{\mathbb{I}}$ AND FOLKER HERRMANN \\ Forschungszentrum Rossendorf e.V., Institut für Ionenstrahlphysik und Materialforschung, \\ PF 510119, D-01314 Dresden, Germany
}

\begin{abstract}
The existence of hydrogen in $\mathrm{Pd}-\mathrm{O}$-bearing aggregates, which together with iron oxides form the characteristic dark encrustation of an ouro preto nugget of Gongo Soco, Minas Gerais, Brazil, is confirmed by elastic recoil detection analysis with a heavy-ion microbeam (micro-ERDA). Hydrogen is lost from Pd-O-bearing areas during the micro-analyses, but not from goethite. The data indicate that the $\mathrm{Pd}-\mathrm{O}-\mathrm{H}$ phase is unstable compared to goethite, giving support to previous observations that it is a transient phase in a transformation to native palladium.
\end{abstract}

Keywords: hydrogen, elastic recoil detection analysis, Pd-O-bearing compound, ouro preto nugget, Gongo Soco, Minas Gerais, Brazil.

\section{SOMMAIRE}

L'existence d'hydrogène dans des aggrégats contenant une phase à $\mathrm{Pd}-\mathrm{O}$, qui constitue, avec des oxydes de fer la patine sombre caractéristique d'une pépite de ouro preto prélevée à Gongo Soco, Minas Gerais, Brazil, est confirmée par une analyse par détection du recul élastique avec un micro-faisceau d'ions lourds (technique micro-ERDA). L'hydrogène est libéré des régions contenant la phase $\mathrm{Pd}-\mathrm{O}$ au cours des analyses, mais non de la goethite. Les données montrent ainsi que la phase à Pd-O-H est instable par rapport à la goethite, et étayent l'hypothèse fondée sur les observations antérieures qu'il s'agit d'une phase transitoire dans une transformation en palladium natif.

(Traduit par la Rédaction)

Mots-clés: hydrogène, analyse par détection du recul élastique, composé contenant $\mathrm{Pd}-\mathrm{O}$, pépite de ouro preto, Gongo Soco, Minas Gerais, Brésil.

\section{INTRODUCTION}

Evidence for the existence of natural oxygen-bearing compounds of palladium dates back to the nineteenth century (Gardner 1826, Johnson \& Lampadius 1837 , but their occurrence has only recently been confirmed. The presence of oxygen has been indicated by qualitative energy-dispersion (ED) analysis and also by quantitative electron-microprobe wavelength-dispersion (WD) analysis, from which the oxygen content is calculated by stoichiometry (e.g., Clark et al. 1974,
Vuorelainen et al. 1982, Jedwab 1995, Olivo \& Gauthier 1995, Salpéteur et al. 1995, Hey 1999, Moreno et al. 1999, Nickel 2002), as well as by quantitative measurement of the intensity of an oxygen peak with the electron microprobe (e.g., McDonald et al. 1999, Varajão et al. 1999, Tolstykh et al. 2000, Cabral et al. 2001, 2002a). However, the existence of possible $\mathrm{H}_{2} \mathrm{O}$ - or $\mathrm{OH}-$ bearing $\mathrm{Pd}-\mathrm{O}$ compounds has remained essentially conjectural. The anhydrous nature of a $\mathrm{Pd}-\mathrm{Pb}$ oxide from Penikat, Finland, was inferred by infrared-absorption spectroscopy (Barkov et al. 1999). On the other hand,

$\S$ Present address: Rua Coelho Neto, no. 32/apt. 704, 22231-110 Rio de Janeiro - RJ, Brazil. E-mail address: cabral70tricolor@yahoo.com.br

II E-mail address: d.grambole@fz-rossendorf.de 
the presence of hydrogen has been suggested for a $\mathrm{Pd}-$ $O$ phase or phases from Lavatravo, Madagascar, on the basis of excess oxygen compared to stoichiometric palladium monoxide, PdO (McDonald et al. 1999). Low analytical totals and the formation of microcracks under the electron beam have been considered indicative of an unanalyzed volatile component, $\mathrm{H}_{2} \mathrm{O}$ or $\mathrm{OH}$, in $\mathrm{Pd}-\mathrm{O}$ aggregates from Minas Gerais, Brazil (Cabral et al. 2002b, 2003).

We here report data from elastic recoil detection analysis with a heavy-ion microbeam (micro-ERDA), which provide the first confirmation of hydrogen in $\mathrm{Pd}-$ $\mathrm{O}$-bearing ouro preto. The $\mathrm{Pd}-\mathrm{O}$ material from Minas Gerais is a distinctive component of the ferruginous encrustations that give the characteristic dark color to the historically famous ouro preto (Jedwab 1995, Jedwab \& Cassedanne 1998, Cabral et al. 2001, 2003, and references therein). The material occurs as an oxidation-induced halo on a precursor Pd-bearing mineral and is unstable, i.e., it tends to evolve to native palladium (Cabral \& Lehmann 2003).

\section{EXPERIMENTAL}

\section{Sample material}

The sample material is a gold nugget about $1.5 \mathrm{~cm}$ across, recovered in a Knelson concentrator at the Gongo Soco iron ore plant. This gold nugget (sample GS-Au-22) and the specular-hematite-rich vein-style $\mathrm{Au}-\mathrm{Pd}$ mineralization of Gongo Soco are described elsewhere (Cabral 2003). The gold is alloyed with silver ( $~ 8 \mathrm{wt} . \% \mathrm{Ag})$, with subordinate amounts of palladium (up to 0.3 wt.\% Pd), but it contains abundant inclusions of Pd-bearing selenide minerals, including chrisstanleyite, $\mathrm{Ag}_{2} \mathrm{Pd}_{3} \mathrm{Se}_{4}$, and unnamed $\mathrm{Sb}-\mathrm{Ag}-\mathrm{Hg}-$ bearing selenides of palladium (Cabral 2003). The gold nugget studied consists of fragments of gold cemented by specular hematite, with which goethite and, the Pd$\mathrm{O}$ compound occur. These minerals, of which the $\mathrm{Pd}-\mathrm{O}$ compound is characteristic, give the typical dark color of ouro preto. It differs, nevertheless, from other nuggets of ouro preto from Gongo Soco, which commonly have higher contents of palladium alloyed with gold and inclusions of arsenide-antimonides of palladium compositionally close to mertieite-II, $\mathrm{Pd}_{8}(\mathrm{Sb}, \mathrm{As})_{3}$, and isomertieite, $\mathrm{Pd}_{11} \mathrm{Sb}_{2} \mathrm{As}_{2}$ (Cabral et al. 2002c).

Two sites of gold-encrusting $\mathrm{Pd}-\mathrm{O}$-bearing aggregates of specular hematite were investigated in this study. At the first site, the $\mathrm{Pd}-\mathrm{O}$ phase has abundant microcracks and is situated between an aggregate of platy hematite and a goethite-like phase (Fig. 1a). At the second site, the $\mathrm{Pd}-\mathrm{O}$ phase looks more massive, i.e., it lacks the prominent microcracks observed at the first site, and occurs in the interstices of crystals of platy hematite (Fig. 2a). Reconnaissance electron-microprobe analyses indicate that the $\mathrm{Pd}-\mathrm{O}$ phase contains a considerable amount of copper (up to $13 \mathrm{wt} \%$ ), subordi- nate gold, iron and manganese (amounting to a few wt.\%), and traces of mercury ( $<1 \mathrm{wt} . \%)$ (Table 1$)$. The analytical totals are below $100 \mathrm{wt} . \%$; oxygen is the only missing element detected by energy-dispersion analysis. However, the metal content indicated in some microanalyses (totaling 94-95 wt.\%) suggests that the amount of oxygen is insufficient to account for a PdO-type compound, i.e., some of the $\mathrm{Pd}-\mathrm{O}$ phase under investigation may represent oxygen-deficient $\mathrm{Pd}-\mathrm{Cu}$ compounds.

\section{Hydrogen measurement}

The distribution of hydrogen in $\mathrm{Pd}-\mathrm{O}$-bearing areas was obtained by micro-ERDA using the nuclear microprobe at the $3 \mathrm{MV}$ Tandetron accelerator of the Forschungszentrum Rossendorf, Dresden (Herrmann \& Grambole 1995). The Pd-O-bearing samples were bombarded with $16 \mathrm{MeV} \mathrm{Si}^{5+}$ ions at an incident angle of $20^{\circ}$ relative to the sample surface. The beam, focused to a diameter of about $3 \mu \mathrm{m}$, was electromagnetically scanned over the sample. Because of the glancing incidence, a lateral resolution of about $3 \times 10 \mu \mathrm{m}^{2}$ was obtained. The recoiled hydrogen atoms were measured by a silicon surface-barrier detector covered by a $10 \mu \mathrm{m}$ Al foil to stop the Si ions scattered in the sample. In this way, it was possible to measure hydrogen (in principle also helium, but no heavier elements) up to a depth of some hundred nanometers. Simultaneously to the detection of the hydrogen ion, the X-rays induced by the $\mathrm{Si}$ beam were detected by a Si(Li)-PIXE (Particle Induced $\mathrm{X}$-ray Detection) detector. The detectors for measuring the hydrogen ions and the X-rays were situated at angles of $30^{\circ}$ and $150^{\circ}$, respectively, relative to the incident beam. The amplified signals of the detectors were analyzed with two analog-to-digital converters (ADC). These digital data were stored, together with the $\mathrm{X}-\mathrm{Y}$ coordinates of the scanned beam, event by event on a hard disk. During the measurement, up to four elementdistribution maps and the spectra could be observed

\begin{tabular}{|c|c|c|c|c|c|c|c|c|c|c|}
\hline & 1 & 2 & 3 & 4 & 5 & 6 & 7 & 8 & 9 & 10 \\
\hline $\mathrm{Pd}$ & 77.48 & 74.61 & 74.42 & 75.25 & 78.89 & 76.55 & 77.28 & 77.64 & 78.08 & 78.27 \\
\hline $\mathrm{Cu}$ & 7.43 & 7.87 & 9.59 & 7.09 & 12.02 & 11.93 & 12.97 & 12.88 & 11.99 & 12.16 \\
\hline $\mathrm{Au}$ & 2.84 & 2.21 & 3.32 & 2.00 & 1.00 & 1.00 & 1.49 & 2,22 & 1.78 & 1.22 \\
\hline $\mathrm{Hg}$ & $<0.2$ & $<0.2$ & 0.72 & 0.22 & 0.54 & 0.45 & 0.44 & 0.51 & 0.48 & 0.41 \\
\hline $\mathrm{lie}$ & 0.24 & 0.23 & 0.68 & 0.81 & 1.08 & 0.42 & 2.58 & 0.82 & 0.87 & 1.72 \\
\hline $\mathrm{Mn}$ & 1.45 & 2.21 & 0.99 & 3.05 & 0.53 & 0.65 & 0.64 & 0.75 & 1.14 & 0.52 \\
\hline Total & 89.44 & 87.13 & 89.72 & 88.42 & 94.06 & 91,00 & 95.40 & 94.82 & 94.34 & 94.30 \\
\hline
\end{tabular}

The electron-microprobe analyses were performed at $20 \mathrm{kV}$ and $40 \mathrm{nA}$ with a Cameca SX100 (TU Clausthal). The following X-ray lines and standards were used: pure metals ( $\mathrm{Au} L \alpha, \mathrm{Cu} K \alpha, \mathrm{Pd} L \alpha, \mathrm{Pt} L \alpha, \mathrm{Se} K \alpha), \mathrm{HgTe}(\mathrm{Hg} L \alpha), \mathrm{Fe}_{2} \mathrm{O}_{3}(\mathrm{Fe} K \alpha), \mathrm{MnSiO}_{3}$ $(\mathrm{MnK} \alpha)$ and InSb ( $\mathrm{S} b L \alpha)$. Platinum, selenium and antimony were sought, but are below the detection limit of $0.3,0.2,0.1$ wt. $\%$, respectively. Column headings: $1-4$ : first site (Fig. 1a), 5-10: second site (Fig. 2a). Compositions are reported in wt.\%. 
online. By reason of this event-by-event storage, the loss of hydrogen during ion bombardment and also differences in the elemental composition could be evaluated off-line (i.e., after the measurement) for several areas in the sample.

\section{Results AND Discussion}

The distribution of hydrogen is shown in Figures 1 and 2. At the first site (Fig. 1a), hydrogen is present within the Pd-rich domain ( $\mathrm{Pd}-\mathrm{O}$ phase, Figs. $1 \mathrm{~b}, \mathrm{c})$, but concentrated in Fe-rich domains (Figs. 1c, d). The Fe-rich areas with hydrogen (e.g., domain 2 in Fig. 1c) and without hydrogen (e.g., domain 3, Fig. 1c) correspond respectively to a goethite-like mineral (domain 2) and hematite (domain 3). At the second site (Fig. 2a), hydrogen is associated with Pd-rich areas containing a Pd-O phase (Figs. 2b, c).

The hydrogen in the Pd-O areas is unstable. During micro-analysis of the first site, hydrogen was lost from the Pd-O-bearing area (Fig. 3a). However, the hydrogen content of the goethite-like mineral of domain 2 remained constant (Fig. 3b). Hydrogen also was lost from the Pd-O-bearing area of the second site (Fig. 3c). This behavior suggests that there are two types of hydrogen bonds, of which those of the goethite-like mineral are more or less stable and not broken by the incident ions, but the kind of linkage cannot be distinguished by this method.

The concentrations of hydrogen in the samples were calculated by a PC algorithm for ERDA (Spaeth et al. 1998) using values of stopping power from Ziegler (1980). They were averaged over the whole domain and over a depth of about 50 to $250 \mathrm{~nm}$, i.e., no surface hydrogen was included into the evaluation. Since hydrogen was lost during the measurement (Fig. 3), the concentration was extrapolated to a charge of $\mathrm{Q}=0 \mathrm{nC}$. The concentrations are as follows: 1) Domain 1, $\mathrm{Pd}-\mathrm{O}$ phase (Fig. 1c): $6.3 \pm 2.4$ at.\% H, 2) Domain 2, goethite-like phase (Fig. 1c): $11.2 \pm 2.2$ at. $\% \mathrm{H}$, and 3) Domain 4 , Pd-O phase (Fig. 2 c): $8.1 \pm 2.7$ at. $\%$ H. The errors quoted arise mainly by the fitting procedures used (Fig. 3). Here, it should be noted that the measured content of hydrogen in domain 2 is less than that of ideal goethite, $\mathrm{FeOOH}(25$ at. $\% \mathrm{H})$. The reason for this difference may be attributed to: (1) the spectrum summation from parts beyond the boundary of the goethite-like mineral, and (2) probable inhomogeneity of the mineral surface. The hydrogen escape on ion bombardment follows an exponential curve in the $\mathrm{Pd}-\mathrm{O}-\mathrm{H}$ phase (Figs. $3 \mathrm{a}, \mathrm{c})$ and a relatively stable hydrogen "background" can be observed in Figure 3c at about 25 counts/262 nC, which corresponds to about 4.0 at.\% $\mathrm{H}$.

This study demonstrates that the $\mathrm{Pd}-\mathrm{O}$-bearing phase, which characterizes an ouro preto nugget of Minas Gerais, contains hydrogen. The hydrogen is most likely related to $\mathrm{H}_{2} \mathrm{O}$, as suggested by the desiccationlike microcracks at the first site (Fig. 1a), and the fact that the hydrogen content of the $\mathrm{Pd}-\mathrm{O}$-bearing domains decreases during measurement. This behavior is different from that displayed by goethite, where hydrogen remains constant. In other words, the $\mathrm{Pd}-\mathrm{O}-\mathrm{H}$-bearing compound is unstable compared to goethite. In the supergene environment, where goethite is stable, the $\mathrm{Pd}-$ $\mathrm{O}-\mathrm{H}$-bearing species would thus be metastable. This fact would explain why such compound is deficient in oxygen, eventually giving rise, via a deoxygenationdehydration process, to native palladium (Cabral \& Lehmann 2003; cf. McDonald et al. 1999, Cabral et al. 2003). Native palladium would therefore seem to be the stable phase of palladium under supergene conditions.

\section{ACKNOWLEDGMENTS}

ARC acknowledges a doctoral scholarship by the Deutscher Akademischer Austauschdienst (DAAD). The sample material (the ouro preto nugget) was provided by the Gongo Soco mine staff (Companhia Vale do Rio Doce, CVRD). The mine staff, particularly Orlando Garcia, Antônio Abdo, Muriel Innocentini, Edivando, Toco, Pimenta, Antônio "Negão", just to name a few, is sincerely thanked for supporting the field work by ARC. Klaus Herrmann (TU Clausthal) carefully assisted in the electron-microprobe analysis. The authors are grateful to the referees, M. Tabacniks and D.J. Cherniak, for the useful suggestions, and to Robert F. Martin for his careful editorial handling.

\section{REFERENCES}

Barkov, A.Y., Halkoaho, T.A.A., Roberts, A.C., Criddle, A.J., Martin, R.F. \& PAPUnen, H. (1999): New Pd-Pb and $\mathrm{Pb}-\mathrm{V}$ oxides from a bonanza-type PGE-rich, nearly BMSfree deposit in the Penikat layered complex, Finland. Can. Mineral. 37, 1507-1524.

CABral, A.R. (2003): Palladian Gold Mineralisation (Ouro Preto) in Brazil: Gongo Soco, Itabira and Serra Pelada. $\mathrm{Ph} . D$. thesis, Technische Universität Clausthal, ClausthalZellerfeld, Germany, http://bibliothek.tu-clausthal.de/ OPUS/volltexte/2003/19/pdf/Dissertation_ARCabral_ Palladian_gold.pdf

\& LeHMANN, B. (2003): A two-stage process of native palladium formation at low temperatures: evidence from a palladian gold nugget (Gongo Soco iron ore mine, Minas Gerais, Brazil). Mineral. Mag. 67, 453-463.

KwitKo-Ribeiro, R. \& Cravo Costa, C.H. (2002a): Palladium and platinum minerals from the Serra Pelada $\mathrm{Au}-\mathrm{Pd}-\mathrm{Pt}$ deposit, Carajás mineral province, northern Brazil. Can. Mineral. 40, 1451-1463.

Galbiatti, H.F. \& Pereira, M.C. (2002b): Palladseite and its oxidation: evidence from $\mathrm{Au}-\mathrm{Pd}$ vein-type mineralization (jacutinga), Cauê iron-ore mine, Quadrilátero Ferrífero, Minas Gerais, Brazil. Mineral. Mag. 66, 327-336. 

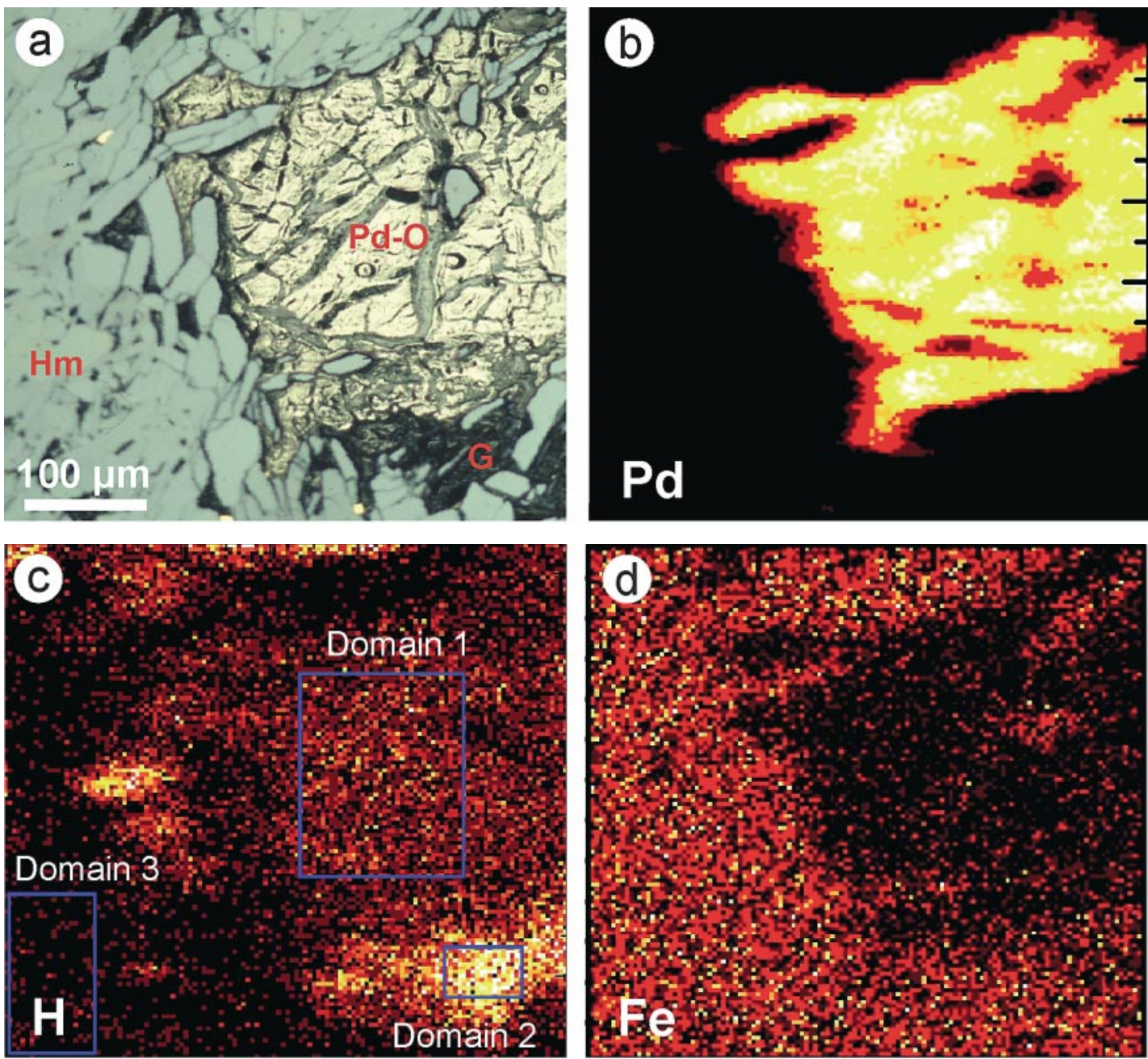

FIG. 1. a. Photomicrograph (reflected light, oil immersion) of a Cu-bearing $\mathrm{Pd}-\mathrm{O}$ phase (Pd-O), with abundant microcracks, located between an aggregate of hematite $(\mathrm{Hm})$ and a goethite-like phase $(\mathrm{G})$. Originally, the $\mathrm{Pd}-\mathrm{O}$ phase had a dark grey color. It acquired a whitish color after ion bombardment. b, d. Distribution of palladium (b) and iron (d), obtained by microPIXE with a beam of $16 \mathrm{MeV} \mathrm{Si}^{5+}(\mathrm{Q}=229.4 \mathrm{nC})$. c. Distribution of hydrogen, obtained by micro-ERDA with a beam of 16 $\mathrm{MeV} \mathrm{Si}^{5+}(\mathrm{Q}=2.03 \mu \mathrm{C})$.

\& JONES, R.D. (2002c): Palladian gold and palladium arsenide-antimonide minerals from Gongo Soco iron ore mine, Quadrilátero Ferrífero, Minas Gerais, Brazil. Trans. Inst. Mining Metall. (Sect. B: Appl. Earth Sci.) 111, 74-80.

PIRES, F.R.M., Rocha Filho, O.G. \& InNocentini, M.D. (2001): Palladium-oxygenated compounds of the Gongo Soco mine, Quadrilátero Ferrífero, central Minas Gerais, Brazil. Mineral. Mag. 65, 169-179.
\& ROCHA FILHO,

O.G. (2003): On the association of palladium-bearing gold, hematite and gypsum in an ouro preto nugget. Can. Mineral. 41, 473-478.

Clark, A.M., Criddle, A.J. \& FeJer, E.E. (1974): Palladium arsenide-antimonides from Itabira, Minas Gerais, Brazil. Mineral. Mag. 39, 528-543.

GARDNER, D. (1826): In Imperial Brazilian Mining Association - Reports of the directors addressed to the share-holders. The Philanthropic Society, London, U.K. (117-119). 

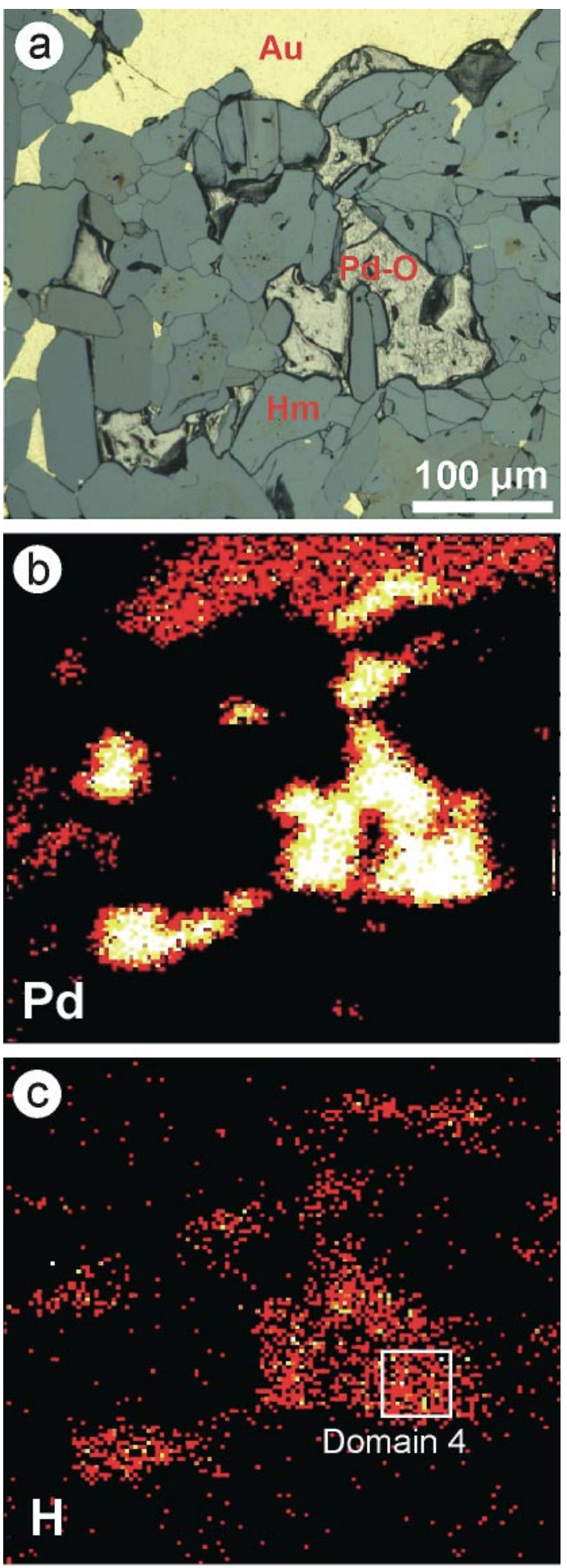
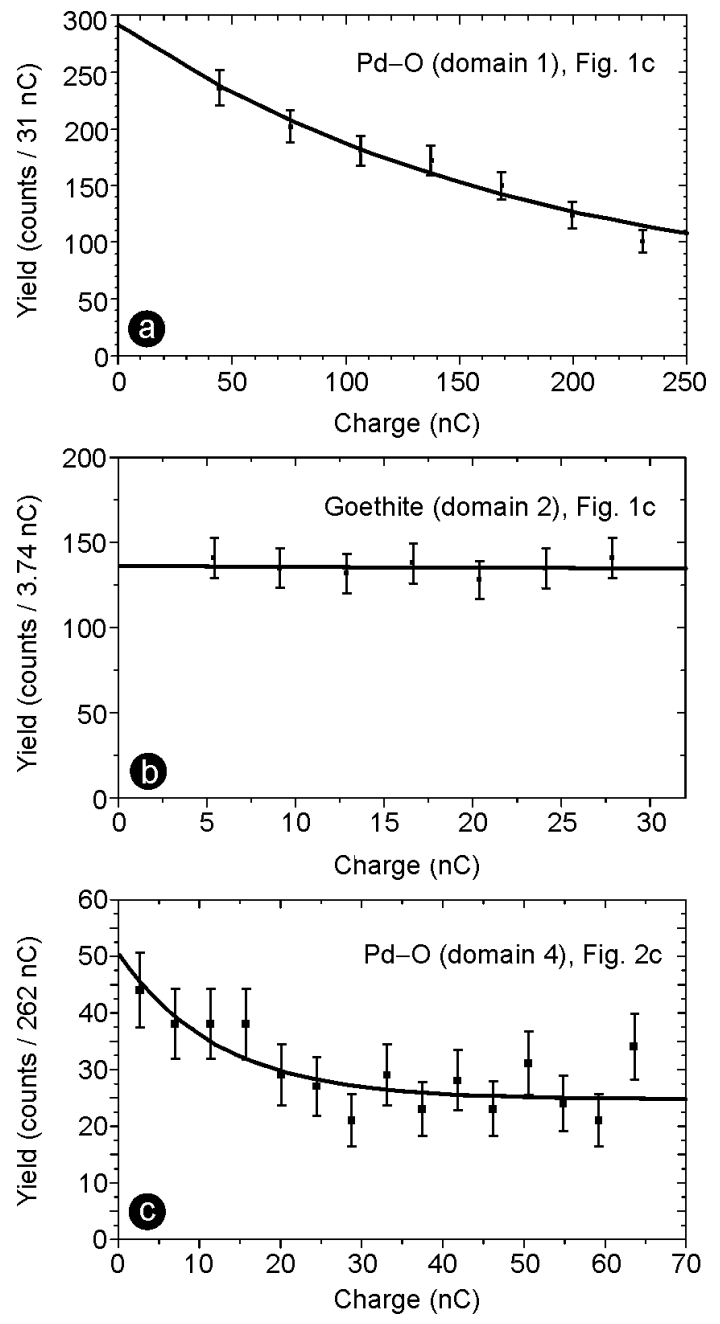

FIG. 3. a-c. Yield of the recoiled hydrogen atoms according to the hydrogen concentration as a function of accumulated charge of the incident $\mathrm{Si}$ ions for (a) $\mathrm{Pd}-\mathrm{O}$ in domain 1 (Fig. 1c), (b) goethite-like phase in domain 2 (Fig. 1c) and (c) $\mathrm{Pd}-\mathrm{O}$ in domain 4 (Fig. 2c).

Fig. 2. a. Photomicrograph (reflected light, oil immersion) of a Cu-bearing $\mathrm{Pd}-\mathrm{O}$ phase $(\mathrm{Pd}-\mathrm{O})$ interstitial to crystals of platy hematite $(\mathrm{Hm})$. The hematite and $\mathrm{Pd}-\mathrm{O}$ phase are part of a dark encrustation on a fragment of gold $(\mathrm{Au})$ that makes up a nugget of ouro preto. The whitish color of the $\mathrm{Pd}-\mathrm{O}$ phase arose from ion bombardment; its original color was dark grey. b. Distribution of palladium, obtained by micro-PIXE with a beam of $16 \mathrm{MeV} \mathrm{Si}^{5+}(\mathrm{Q}=16.4 \mathrm{nC})$. c. Distribution of hydrogen, obtained by micro-ERDA with a beam of $16 \mathrm{MeV} \mathrm{Si}^{5+}(\mathrm{Q}=4 \mu \mathrm{C})$. 
Herrmann, F. \& Grambole, D. (1995): The new Rossendorf nuclear microprobe. Nucl. Instrum. Methods in Phys. Res. B104, 26-30.

Hey, P.V. (1999): The effects of weathering on the UG2 Chromitite reef of the Bushveld Complex, with special reference to the platinum-group minerals. S. Afr. J. Geol. 102, 251-260.

JEDWAB, J. (1995): Oxygenated platinum-group-element and transition-metal ( $\mathrm{Ti}, \mathrm{Cr}, \mathrm{Mn}, \mathrm{Fe}, \mathrm{Co}, \mathrm{Ni}$ ) compounds in the supergene domain. In Platinum Group Elements in Supergene Processes (T. Augé \& E. Stumpfl, eds.). Chron. Rech. Minière 63(520), 47-53.

\& Cassedanne, J. (1998): Historical observations on oxygen-bearing compounds of platinum and palladium in Minas Gerais, Brazil. Can. Mineral. 36, 887-893.

Johnson, P.N. \& LAMPADIUS, W.A. (1837): Ueber brasilianisches Palladgold und dessen Ausbringen und Scheidung. Journal für praktische Chemie 11, 309-315.

McDonald, I., Ohnenstetter, D., Ohnenstetter, M. \& VAughan, D.J. (1999): Palladium oxides in ultramafic complexes near Lavatrafo, western Adriamena, Madagascar. Mineral. Mag. 63, 345-352.

Moreno, T., Prichard, H.M., Lunar, R., Monterrubio, S. \& FISHER, P. (1999): Formation of a secondary platinumgroup mineral assemblage in chromitites from the Herbeira ultramafic massif in Cabo Ortegal, NW Spain. Eur. J. Mineral. 11, 363-378.

NicKel, E.H. (2002): An unusual occurrence of Pd, Pt, Au, Ag, and $\mathrm{Hg}$ minerals in the Pilbara region of Western Australia. Can. Mineral. 40, 419-433.
Olivo, G.R. \& GAUTHIER, M. (1995): Palladium minerals from the Cauê iron mine, Itabira district, Minas Gerais, Brazil. Mineral. Mag. 59, 455-463.

Salpéteur, I., Martel-Jantin, B. \& Rakotomanana, D. (1995): Pt and Pd mobility in ferralitic soils of the West Adriamena area (Madagascar). Evidence of a supergene origin of some Pt and Pd minerals. In Platinum Group Elements in Supergene Processes (T. Augé \& E. Stumpfl, eds.). Chron. Rech. Minière 63(520), 27-45

Spaeth, C., Richter, F., Grigull, S. \& Kreissig, U. (1998): Conversion algorithm for ERDA multielement spectra and its application to thin-film problems. Nucl. Instrum. Methods Phys. Res. B140, 243-250.

Tolstykh, N.D., Krivenko, A.P., Lavrent'ev, Y.G., Tolstykh, O.N. \& KorolyuK, V. (2000): Oxides of the $\mathrm{Pd}-\mathrm{Sb}-\mathrm{Bi}$ system from the Chiney massif (Aldan Shield, Russia). Eur. J. Mineral. 12, 431-440.

Varajão, C.A.C., Fialin, M., Colin, F. \& Vieillard, P. (1999): Chemical composition including oxygen of an undefined $\mathrm{Pd}-\mathrm{Cu}$-bearing phase from Maquiné mine, Minas Gerais, Brazil. Zbl. Geol. Paläont. Teil I, 871-881.

Vuorelainen, Y., HäKli, T.A., HÄnninen, E., Papunen, H., REINO, J. \& TÖRNROOS, R. (1982): Isomertieite and other platinum-group minerals from the Konttijärvi layered mafic intrusion, northern Finland. Econ. Geol. 77, 15111518.

ZIEGLER, J.F. (1980): Handbook of Stopping Cross Sections for Energetic Ions in All Elements. Pergamon, New York, N.Y.

Received December 21, 2003, revised manuscript accepted February 14, 2004. 

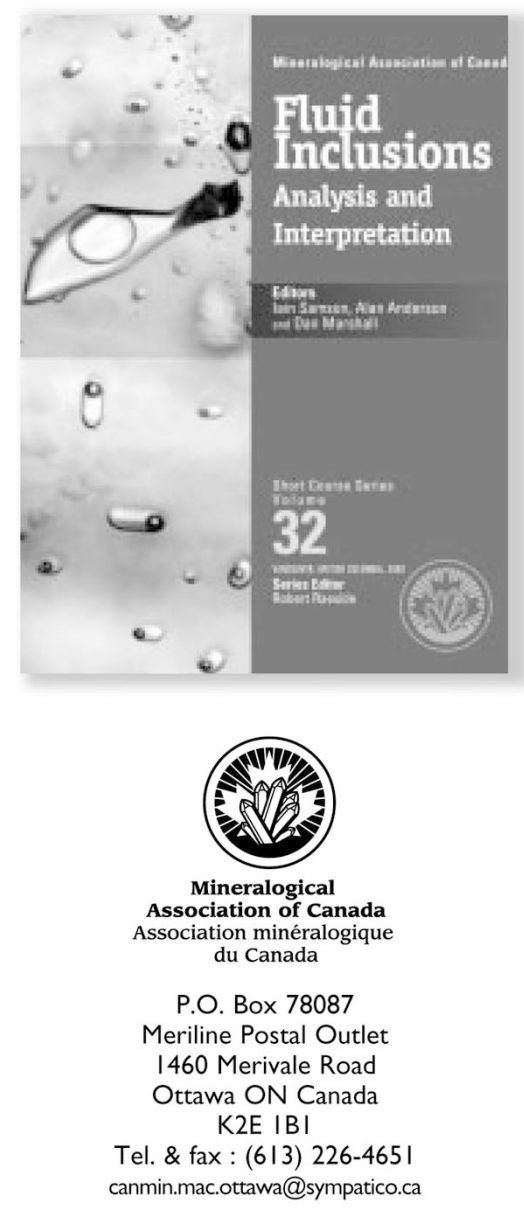

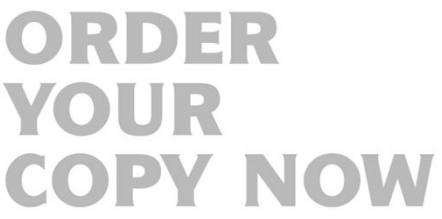

Short-Course Volume 32

Fluid Inclusions: Analysis and Interpretation

$\longrightarrow$

VERS all the basic and many advanced aspects

of the analysis and interpretation of fluid inclusions:

- what information and data can be obtained from them

- what approaches and techniques can be used

to analyze fluid inclusions

- how data are processed and interpreted

- where the limitations and pitfalls of the various techniques lie.

The accompanying CD-ROM includes fluid inclusion modelling software and figures from the short-course volume.

ISBN 0-921294-32-8

SC32, approx. 300 pages, 2003

US\$45 (outside Canada) CDN\$45 (in Canada)

(Member Price US\$36/CAN\$36)

Please send copy(ies) of Fluid Inclusions: Analysis and Interpretation, $\$ 45^{*}$ each

* CDN\$ in Canada. Other countries US\$.

$-20 \%$ discount for members

Total

Method of payment

Prices include shipping by surface mail and handling

$\square$ Cheque $\square$ Money order $\square$ Credit card

I authorize the Mineralogical Association of Canada to charge the TOTAL AMOUNT DUE to my: $\square$ Visa $\square$ MasterCard $\square$ EuroCard

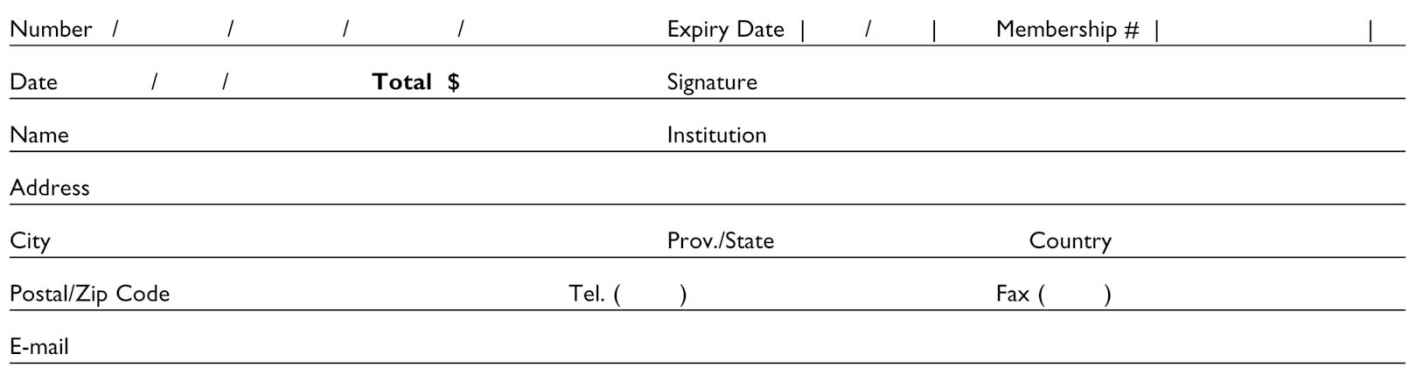

\section{Order onune whwomineralogicalassocichilonoced}

